\title{
Tafsir Pendidikan Tauhid Keluarga dalam Qs. al-Baqarah 132-133
}

\author{
Siti Sukrilah \\ Universitas Darul Islam (UNDARIS) Kabupaten Semarang \\ Email: sitisukrilah02@gmail.com
}

\begin{abstract}
Abstrak
Fokus penelitian yang akan dikaji adalah: 1. Bagaimana biografi Ibnu Katsir. 2. Bagaimana konsep pendidikan Tauhid dalam Islam menurut al Qur'an Surat al Baqarah ayat 132-133. 3. Bagaimana konsep pendidikan tauhid dalam keluarga menurut Ibnu Katsir. 4. Relevansi konsep pendidikan tauhid dalam keluarga menurut Tafsir Ibnu Katsir di kehidupan sekarang. Penelitian ini merupakan penelitian kepustakaan (library research), sedangkan dalam pengumpulan datanya menggunakan metode dokumetasi (documentation research method), analisis data yang digunakan dalam skripsi ini adalah analisis isi (content analysis). Hasil penelitian menyimpulkan bahwa: 1. Ibnu Katsir adalah seorang ahli tafsir dan sejarah ternama. Ia juga seorang ahli fiqih dan ahli hadis. Ibnu Katsir lahir pada tahun $700 \mathrm{H} / 1300 \mathrm{M}$ di timur Bashri yang masuk wilayah Damaskus dan wafat pada tahun $774 \mathrm{H}$ di Damaskus. Salah satu karya ilmiah Ibnu Katsir yang akan dibahas dalam skripsi ini adalah kitab Tafsîr al Qurân al 'Azîmyang termasyhur dengan sebutan Tafsir Ibnu Katsirpada Qur'an Surat al Baqarah ayat 132-133. 2. Konsep pendidikan tauhid dalam Islam menurut al Qur'an Surat al Baqarah ayat 132-133 merupakan proses membimbing manusia untuk tetap teguh kepercayaannya bahwa Allah Maha Esa dan hanya tunduk kepada-Nya sampai akhir hayat. 3. Sedangkan konsep pendidikan tauhid dalam keluarga menurut Ibnu Katsir dalam Qur'an Surat al Baqarah ayat 132133 adalah, upaya membina manusia dalam menyerahkan diri secara
\end{abstract}


mutlak kepada Allah SWT sepanjang hayatnya dalam keluarga secara berkesinambungan sampai keturunannya di masa depan kelak meskipun berbeda cara atau metode dalam pelaksanaannya. 4. Adapun relevansi pendidikan tauhid dalam keluarga dimasa sekarang adalah bahwa pendidikan tauhid di masa sekarang ini harus berusaha lebih keras lagi untuk terus memperhatikan dengan membuat metode yang variatif agar anak didik dapat mengikuti dengan nyaman dan tidak terbebani akan aturan-aturan yang harus dilaluinya untuk mencapai tujuan dari pendidikan tauhid ini.

This research focus on: 1) the biography of Ibn Kathir 2) the educational concept of Tawheed in Islam according to the Quran Surah al-Baqarah verse 132-133 3) the concept of monotheism education in the family according to Ibn Kathir 4) The relevance of the educational concept of monotheism in the family according to Ibn Kathir's interpretation in the present. It is a library research, which uses documentation to collect the data, and content analysis to analyze it. The study concluded that 1) Ibn Kathir $(700 \mathrm{H}-774 \mathrm{H})$ is an interpreter, renowned history, expert jurists and scholars of hadith. One of his scientific works is the book of Tafseer al Quran al 'Azîm, Qur'an Surah al-Baqarah verse 132-133. 2) The educational concept of monotheism is the process of guiding people to remain belief in Allah Almighty and subject only to Him until the end 3) While the concept of monotheism education in the family is an effort to develop human who rely on his self to God during his entire life in the family on an ongoing basis until the later offspring in the future despite the different ways in its implementation. 4) Monotheism in the present education must strive harder to continue to pay attention in making varied methods so that students can follow comfortably with the rules that must be gone through to reach the purpose of tawheed education.

Kata Kunci: Konsep Pendidikan Tauhid, Keluarga, Ibnu Katsir

\section{Pendahuluan}

Pendidikan sebagai suatu bentuk kegiatan manusia dalam kehidupannya juga menempatkan tujuan sebagai sesuatu yang hendak dicapai, baik tujuan yang dirumuskan itu bersifat abstrak sampai pada 
rumusan-rumusan yang dibentuk secara khusus untuk memudahkan pencapaian yang lebih tinggi. Pendidikan merupakan bimbingan terhadap perkembangan manusia menuju ke arah cita-cita tertentu, maka yang merupakan masalah pokok bagi pendidikan ialah memilih arah atau tujuan yang ingin dicapai (Hasbullah, 2009 : 10). Dengan begitu hal yang paling utama adalah dalam rangka penghambaan diri terhadap Allah SWT dengan waktu yang telah dianugerahkan kepada manusia selama masih hidup.

Prof. Dr. Kamal Hasan memberikan penjelasan pendidikan dalam perspektif Islam, adalah suatu proses seumur hidup untuk mempersiapkan seseorang agar dapat mengaktualisasikan peranannya sebagai khalifatullah di muka bumi. Dengan kesiapan tersebut, diharapkan dapat memberikan sumbangan sepenuhnya terhadap rekonstruksi dan pembangunan masyarakat dalam mencapai kebahagiaan dunia dan akhirat (Kurniasih, 2010 : 63).Hal itu dimulai dari lingkup yang paling kecil yaitu sebuah keluarga tempat dimana seorang anak tinggal.

Orangtua memiliki kewajiban untuk membentuk generasi pengubah peradaban. Salah satu caranya adalah dengan mengembangkan kreativitas anak-anak dengan nilai-nilai spiritualitas. Berdasarkan ajaran Islam, tanggung jawab pendidikan, pembentukan kualitas, dan kepribadian anak merupakan tanggung jawab kedua orang tua (Kurniasih, 2010 : 149). Tidak bisa orang tua menyalahkan orang lain jika anak sedang terpengaruh oleh budaya luar yang tidak sesuai dengan norma. 
Pada masa sekarang ini, pengaruh keluarga mulai melemah karena perubahan sosial, politik, dan budaya yang terjadi. Keluarga telah kehilangan fungsinya dalam pendidikan. Sebagian tanggung jawab keluarga beralih kepada orang-orang yang menggeluti profesi tertentu, seperti halnya pabrik roti, benang, tekstil dan lain-lain. Pabrik roti, benang, tekstil berperan sebagai sesuatu yang dijadikan tumpuan bagi orang tua dalam memenuhi kebutuhan untuk keluarga sehari-hari. Jika diamati, hal tersebut telah mengambil waktu dan tenaga yang banyak dari setiap harinya sehingga waktu untuk keluarga adalah waktu untuk istirahat. Di sinilah orang tua seharusnnya sadar bahwa anak-anak sekarang mengalami kerugian yang besar. Karena kurangnya kebersamaan antara anak dengan orang tua, sehingga anak kurang memiliki kedekatan emosional dengan mereka yang menyebabkan anak kurang begitu peka terhadap mereka.Di sini keluarga memiliki peranan yang besar dalam mendidik dan mempengaruhi anak-anak (Zurayk, 1994 : 21). Dengan waktu-waktu yang telah dilalui, maka apa saja yang telah dilihat, didengar, dan dirasakan anak merupakan suatu pembelajaran untuknya di masa depan nanti. Banyak sekali orang tua tidak dapat lagi mendampingi serta medidik anaknya karena waktu yang telah tersita oleh pekerjaan mereka untuk memenuhi materi keluarga.

Lembaga pendidikan, harus melatih anak didiknya untuk bersikap sopan, mempunyai sikap sosial yang baik, menjadi warga negara yang baik, disiapkan untuk mengambil tempat yang tepat di dunia, untuk bekerja sama dengan orang lain namun memiliki pandangan mandiri, untuk mematuhi aturan pendisiplinan (Kane, 2004 : 216). Pendidikan 
anak tergantung sejauh mana kerja sama antara sekolah dan keluarga, guru dan orang tua (Zurayk, 1994 : 23). Tidak hanya dilepas begitu saja setelah diserahkan di dalam sebuah lembaga pendidikan, kemudian dengan mudah mengkambing hitamkan lembaga pendidikan jika anak berbuat sebuah penyelewengan. Akan tetapi tetap ada pantauan dan interaksi yang mendukung untuk perkembangan pendidikan anak hingga kembali berkumpul keluarga.

Untuk membentuk anak yang saleh, dibutuhkan pendidikan yang terarah sebagaimana diajarkan al-Qur'an. Pendidikan agama, pendidikan budi pekerti dan pendidikan moral perlu ditanamkan sedini mungkin kepada anak sehingga terbentuk karakter anak yang jelas menjadi dambaan orang tua, nusa, bangsa dan agamanya (Marijan, 2012 : 18). Gangguan pada pertumbuhan kepribadian seseorang mungkin disebabkan pecahnya kehidupan keluarga batih (keluarga yang terdiri dari: suami/ayah, istri/ibu, dan anak-anak yang belum menikah) secara fisik maupun mental (Soekanto; 23). Banyak dijumpai terbentuknya keluarga yang kurang persiapan matang sebelumnya, sehingga banyak terjadi masalah-masalah yang tidak bisa di atasi dan menimbulkan meluasnya masalah hingga dampaknya sampai ke masyarakat.

Orang tua tidak bisa cuci tangan terhadap moral anak. Telah menjadi pendapat umum bahwa keteladanan lebih berharga bagi tumbuh dan berkembangnya moral anak daripada seribu nasihat. Keteladanan yang diikuti pembelajaran adalah dua perilaku yang menyatu, membangun bangunan kokoh tak mudah untuk digoyahkan (Marijan, 2012 : 40). Berpedoman pada al-Qur'an mengenai kisah-kisah orang 
terdahulu yang berpegang teguh pada tali agama Allah layaknya dalam Surat al-Baqarah ayat 132-133 terdapat nama-nama seperti Ibrahim, Ismail dan Iskhak, Ya'qub.

Bagi kaum muslimin, Ibrahim adalah manusia teladan dalam hal ketaatan kepada Allah dan keteguhan menegakkan tauhid. Ia digambarkan oleh al-Qur'an sebagai manusia pilihan, kekasih Allah, saleh, siddik, muslim, hanif, dan lain sebagainya. Tidak mengherankan bahwa institusi haji, korban dan khitan, yang dimulai oleh Ibrahim, tetapi dihidupkan oleh Islam (IAIN Syarif Hidayatullah, 1992 : 393).

Dalam Surat al-Baqarah ayat 132-133 terdapat ajaran nilai pendidikan anak yang pastinya memiliki cakupan dengan nilai-nilai pendidikan, penulis tertarik mengetahui konsep pendidikan tauhid dalam keluarga dalam ayat tersebut melalui kajian pustaka atas Tafsir Ibnu Katsir. Ada beberapa bahasan menarik tentang dalam kitab Tafsir Ibnu Katsir berkenaan tentang konsep tauhid pada surat al-Baqarah ayat 132133 dikaitkan dengan kehidupan saat ini.

\section{Metode Penelitian}

Metode penelitian ini merupakan penelitian pustaka (library reseach) yang difokuskan pada penelusuran dan penelaahan literature serta bahan pustaka lainnya.

\section{Pendidikan Tauhid}

Istilah pendidikan berasal dari kata didik. Kata didik mendapatkan awalan "me" sehingga menjadi "mendidik" berarti 
memelihara dan memberi latihan diperlukan adanya sebuah pengajaran, tuntunan dan pimpinan mengenai akhlak dan kecerdasan pikiran. Kemudian pengertian pendidikan adalah proses perubahan sikap dan tingkah laku seseorang atau kelompok orang dalam usaha mendewasakan manusia melalui usaha pengajaran dan pelatihan (Islamuddin, 2012: 3). Kata tauhid berasal dari bahasa Arab tawhîd yang berarti mengesakan. Tauhid adalah meyakini bahwa Allah SWT itu Esa dan tidak ada sekutu bagi-Nya. Kesaksian ini dirumuskan dalam kalimat syahadat lâ ilâha illâ Allâh (tidak ada Tuhan selain Allah). Kata tauhid adalah bentuk masdar (infinitif) dari kata kerja lampau wahhada yang merupakan derivasi dari akar kata wahdah yang berarti keesaan, kesatuan, dan persatuan (Dewan Redaksi Ensiklopedi, 1994 : 90).

Berdasarkan beberapa istilah di atas, maka konsep pendidikan tauhid yang dimaksud penulis adalah gambaran dari proses perubahan sikap dan tingkah laku seseorang dalam mengetahui, mengenal dan mendekatkan diri kepada Allah Yang Maha Esa.

Sedangkan istilah keluarga dalam arti sempit didasarkan pada hubungan darah yang terdiri atas ayah, ibu, dan anak yang disebut dengan keluarga inti. Sedangkan dalam arti luas, semua fihak yang ada hubungan darah sehingga tampil sebagai clan atau marga yang dalam berbagai budaya setiap orang memiliki nama kecil dan nama keluarga atau marga (Ulfatmi, 2011: 20). Maka, konsep pendidikan tauhid dalam keluarga adalah gambaran mewujudkan suasana belajar untuk mengembangkan segala potensi secara sadar disertai keyakinan bahwa selalu ada Allah yang Maha Esa dalam sebuah kelompok dimana 
seseorang tinggal untuk bekal manusia dalam menjalani sebuah kehidupan sebagai khalifatullah di bumi.

Surat al-Baqarah adalah surat yang terpanjang dalam al-Qur'an yang turun di Madinah dalam masa tidak kurang dari sembilan tahun. Panjangnya masa tersebut, ditambah dengan keragaman penduduk Madinah, baik suku, agama, maupun kecenderungan, menjadikan surah ini mengandung 286 ayat yang keseluruhannya terdiri dari dua setengah juz dari tiga puluh juz ayat-ayat al Qur'an.

Al-Baqarah (seekor sapi) adalah namanya yang paling populer. Ini karena dalam surah ini ada uraian tentang sapi yang diperintahkan Allah SWT kepada Bani Israil (penganut agama Yahudi) untuk menyembelihnya dalam rangka menampik tuduh menuduh antara mereka menyangkut pembunuhan yang tidak dikenal siapa pelakunya.

Ia dinamai juga as Sinâm yang berarti puncak, karena tiada lagi puncak petunjuk setelah kitab suci ini. Juga az Zahrâ', yakni terang benderang, karena kandungan surah ini menerangi jalan dengan benderang menuju kebahagiaan dunia dan akhirat, serta menjadi penyebab bersinar terangnya wajah siapa yang mengikuti petunjukpetujuknya (Shihab, 2012: 11-12).

Pada dasarnya, Tafsir Ibnu Katsir merupakan sebuah tafsir yang pengarangnya bertumpu pada penjelasan sekadarnya yang hanya berguna bagi ulama tertentu saja. Kemudian para ulama itu memperdalam topiktopik ayat yang ditafsirkan selaras dengan minat mereka secara terinci dan luas. Penjelasan sekadarnya itu dimaksudkan agar ulama memperdalam pokok-pokok ilmu tafsir selaras dengan kompetensi naluri 
keilmuan dan pemahamannya dalam membahas hal-hal yang kompleks menjadi sederhana dan yang sulit menjadi terurai dan gamblang (Rifa'i, 1999: dalam Pengantar Cetakan Pertama)

\section{Analisis Qur'an Surat Al Baqarah Ayat 132-133}

Dari sekian banyak ajaran al Qur'an, yang paling mendasar adalah ajaran tauhid - dalam pengertian akidah ketuhanan dan ibadah. Allah menciptakan jin dan manusia serta seluruh makhluk-Nya agar mereka bertauhid dalam kedua bidang itu. Berbagai syari'at yang diturunkan Allah pada hakikatnya dalam rangka menegakkan prinsip tauhid (Dahlan, 1997: 209). Prinsip tauhid yang dimaksud di sini bahwa umat Islam menyembah Tuhan yang satu yaitu Allah SWT, Rasulullah sebagai teladan, Alqur'an sebagai pedoman, dan Ka'bah sebagi qiblatnya.

Prinsip tauhid sangat penting bagi setiap orang, karena menurut al Qur'an, keselamatan atau kecelakaan seseorang di akhirat ditentukan oleh benar atau tidaknya ia bertauhid (Dahlan, 1997: 211). Nabi Ya'qub adalah putra Nabi Ishaq, dan Nabi Ishaq adalah putra Nabi Ibrahim dari istri pertamanya Sarah. Selain berputra Ishaq, dari istrinya yang kedua, Hajar, Nabi Ibrahim juga berputra Ismail yang belasan tahun lebih tua dari Ishaq. Dari Ismail inilah diturunkan Nabi Muhammad SAW, penutup para nabi dan rasul. Maka Ibrahim pun sering disebut sebagai "Bapak para nabi". Dari sisnilah pentingnya kedudukan Nabi Ibrahim dalam sistem keimanan islam. Dialah yang dijuluki sebagai "Bapak orang beriman" dalam tiga tradisi agama yaitu Yahudi, Kristen, dan 
Islam (Taufik, $2002: 182$ ).

Kata ووصى بها إبرا هيم بنيه ويعقوب (Ibrahim mewasiatkan ucapan itu kepada anak-anaknya, demikian pula Ya'qub), begitu pentingnya pesan yang hendak disampaikan, sehingga pesan tersebut diulang pada peristiwa sakaratul maut nabi Ya'qub. Ayat-ayat surat al Baqarah ini menyebutkan dua posisi anak. Pertama anak sebagai anak kandung dan kedua anak dalam lingkup satu tempat tinggal yang bukan anak kandung.

Dari penjelasan di atas kata يابني (hai anak-anakku) dapat disimpulkan bahwa anak-anak Ibrahim dan juga anak-anak Ya'qub selain anak kandung juga dalam hal tradisi Arab yang menyebut paman dengan sebutan ayah karena Ismail adalah paman Ya'qub. Di sini dapat dilihat bahwa, anak belajar dari keluarganya dari cara hidup sesuai dengan budaya yang berlaku pada waktu dan tempat tertentu. Keluarga secara tidak langsung telah mengajarkan kepada anak akan budaya keluarga melalui bentuk-bentuk umum yang terlihat seperti dalam berkomunikasi berupa isyarat, bahasa, maupun kosa kata. Dari cara-cara melakukan sesuatu seperti mengamati, berusaha, dan dalam hal sosial seperti gotong royong, saling menghargai dan dalam proses mencapai sesuatu.

Lafal إن الله اصطفى لكم الدين فلا تموتن إلا وأنتم مسلمون (sesungguhnya Allah telah memilih agama ini bagimu, maka janganlah kamu mati kecuali dalam memeluk agama Islam). Agama Islam bukanlah agama ruhani dan akidah saja, akan tetapi Islam adalah agama dan negara, akhlak, ideologi kehidupan dan konstitusi sosial (Zuhaili, 1995: 118). Selain itu, agama merupakan pembatas antara yang halal dan yang haram.Bukan hanya sebagai identitas suatu kaum atau sebagai alat untuk 
memenuhi suatu persyaratan dalam mencapai sesuatu.

Dalam firman Allah:

ما تعبدون من بعدى؟ قالو ا نعبد إلكاك و إله ابا ئك إبر اهيم و إسماعيل و إسحق

(“Apa yang kamu sembah sepeninggalku”.Mereka menjawab."Kami akan menyembah Rabb-mu dan Rabb nenek moyangmu Ibrahim, Ismail dan Ishak"). Percakapan yang menyatakan bahwa pengajaran akan menyembah Allah harus diperhatikan dengan serius, maka dari itu harus dikedepankan dulu pendidikan akan tauhid ini. Jangan sampai pendidikan agama hanya mengisi akan pengertian, dan jauh akan pemahaman dan pengamalan. Dalam prakteknya, anak didik hanya mengerti bahwa Tuhan Maha Melihat akan tetapi anak tetap saja berani mencuri. Anak tahu bahwa manusia sebagai makhluk Tuhan harus yakin akan keberadaan-Nya, namun anak belum tahu apa hakekatnya yakin tersebut.

Kalimat (إلها واحدا (Yaitu Ilah Yang Maha Esa) menunjukkan bahwa tidak ada yang serupa dan tidak boleh menyekutukanNya dengan yang lain. Karena, jika ada yang beranggapan demikian, maka termasuk dosa besar dan tidak akan dapat diampuni. Dahulu, banyak berhala dijadikan Tuhan oleh orang-orang kafir.Sekarang, orang-orang kafir menggiring generasi Islam kepada Tuhan-Tuhan teknologi canggih yang dengan mudah dapat menjadikan manusia lalai.Misalkan, melalui game, film, atau tayangan informasi dari internet yang membungkus kebaikan dengan segudang tipu daya.

Lafal ونحن له مسلمون (dan hanya kepada-Nyalah kami berserah diri) adalah isyarat bahwa manusia harus yakin dalam tunduk dan menyembah 
hanya kepada Allah. Karena, seperti yang dikatakan Ahmad Tafsir bahwa iman ialah rasa, bukan pengertian. Iman yang sebenarnya bukan terletak pada mengerti, melainkan pada rasa iman. Tegasnya rasa selalu melihat Allah atau dilihat Allah. Kondisi begini sama sekali tidak bisa diterangkan dan dipahami akal yang ada di kepala. Memang kunci pendidikan agama itu adalah pendidikan agar anak didik itu beriman, jadi berarti membina hatinya, bukan membina mati-matian akalnya. Pendidikan di rumah yang sesungguhnya paling dapat diandalkan untuk membina hati, membina rasa bertuhan.Iman itu di hati, bukan di kepala (Tafsir, 2008: 188).

Banyak orang yang beranggapan jika seorang anak sudah terlihat rajin dalam beribadah maka hal tersebut sudah cukup bagi orang tua. Namun, manusia tidak tahu apa yang ada di hati seseorang, maka setidaknya keluarga dapat mengetahui secara emosional tentang pribadi seorang anak sehingga orang tua dapat terus mengawasi dan membimbing anak dalam bertauhid.

Para psikolog dan pendidikan menyatakan bahwa, tahun-tahun pertama kehidupan anak merupakan masa paling penting bagi pembentukan kepribadian dan penanaman sifat-sifat dasar. Ini tidak berarti bahwa perkembangan anak terbatas hanya sampai pada tahuntahun tersebut sehingga tidak ada perubahan sesudah itu. Maka dasardasar yang paling penting di dalam kehidupan anak diletakkan pada masa-masa tersebut (Aly dan Munzier, 2003: 201). Apabila anak sudah tumbuh remaja, akan lebih sulit untuk menanamkan nilai-nilai luhur dibandingkan dengan anak pada tahun-tahun pertama setelah lahir yang 
sifat dan kebiasaannya masih dapat diubah.

Jadi, keluarga sebagai pusat pendidikan tidak hanya berpengaruh pada tahun-tahun pertama dari kehidupan anak, tetapi terus berlangsung dalam berbagai fase umur anak. Keluarga secara alami merupakan pusat pendidikan urgen yang pengaruhnya selalu terbawa kedalam pusat pendidikan dan lembaga sosial lainnya. Oleh sebab itu, anak pada hakikatnya merupakan ekspresi kebudayaan keluarga (Aly dan Munzier, 2003: 204). Yang dimaksud dengan kebudayaan keluarga adalah materi; tingkat sosial, pendidikan, dan pikiran; pola-pola hubungan yang berlaku; serta prinsip-prinsip dan nilai-nilai yang mengatur tingkah laku individu keluarga (Aly dan Munzier, 2003: 206). Karenanya, perbaikan terhadap kebudayaan keluarga serta upaya memperkayanya dengan berbagai pengalaman edukatif dan pola-pola tingkah laku yang lurus pada gilirannya akan membias pada perbuatan sekolah dan pusat-pusat pendidikan lainnya. Keluarga secara alami merupakan lingkungan yang real dan definitif, dimana anak dapat berinteraksi dengan berbagai kondisi dan situasinya serta mengetahui dimensi-dimensinya (Aly dan Munzier, 2003: 204).

Menurut Emha Ainun Nadjib bagaimana memperkenalkan Islam dengan cara yang menarik, niscaya harus terus menerus direformasi. Bukan penyesuaian diri terhadap segala kemajuan zaman melainkan tetap berdiri di atas landasan tauhid Islam dengan memodifikasi ungkapanungkapan budayanya (Drawaty dan Safei, 2001: 190). Untuk itu kreatifitas dan do'a selalu dibutuhkan di dalam berbagai waktu dan tempat, maksudnya agar manusia selalu berpikir dalam bertindak dengan 
tidak melupakan bahwa segala sesuatu terjadi semuanya atas kehendak Tuhan.

\section{Relevansi Konsep Pendidikan Tauhid dalam Keluarga di Kehidupan Sekarang}

Dilihat dari segi pendidikan, keluarga merupakan satu kesatuan hidup (sistem sosial) yang menyediakan situasi belajar (Hasbullah, 2009: 87). Salah satu kesalah kaprahan dari para orang tua dalam dunia pendidikan sekarang ini adalah adanya anggapan bahwa hanya sekolahlah yang bertanggung jawab terhadap pendidikan anak-anaknya, sehingga orang tua menyerahkan sepenuhnya pendidikan anaknya kepada guru di sekolah (Hasbullah, 2009: 22). Padahal di sekolah umumnya guru lebih fokus mengajarkan ilmu-ilmu akademis daripada pendidikan tentang bertauhid, meskipun ilmu-ilmu akademis tersebut selalu berkaitan dengan keberadaan Tuhan.

Pada umumnya agama seseorang ditentukan oleh pendidikan, pengalaman dan latihan-latihan yang dilaluinya pada masa kecilnya dulu. Seorang yang pada masa kecilnya tidak pernah mendapatkan didikan agama, maka pada masa dewasanya nanti ia tidak akan merasakan pentingnya agama dalam hidupnya. Lain halnya dengan orang yang diwaktu kecilnya mempunyai pengalaman-pengalaman agama, maka orang itu akan dengan sendirinya mempunyai kecenderungan kepada hidup dalam aturan-aturan agama, terbiasa menjalankan ibadah, takut melangkahi larangan-larangan agama dan dapat merasakan betapa nikmatnya hidup beragama (Daradjat, 1970: 35). 
Sikap anak terhadap sekolah terutama akan dipengaruhi oleh sikap orang tuanya. Begitu juga sangat diperlukan kepercayaan orang tua terhadap sekolah (pendidik) yang menggantikan tugasnya selama di ruangan sekolah. Hal ini sangat penting untuk diperhatikan, mengingat akhir-akhir ini seringnya terjadi tindakan-tindakan kurang terpuji dilakukan anak didik, sementara orang tua seolah tidak mau tahu, bahkan cenderung menimpakan kesalahan kepada sekolah (Hasbullah, 2009: 90). Orang tua tidak boleh berpandangan bahwa setelah anak dimasukkan kedalam lembaga pendidikan orang tua hanya bertanggung jawab dalam hal pembiayaan saja, akan tetapi orang tua tetap berkewajiban membimbing dan memberi arahan bagaimana cara bersikap dimanapun berada kepada anak saat anak tengah bersama dengan keluarga.

Tatkala berbicara tentang metode pendidikan agama di sekolah, salah satu kesimpulan penting ialah bahwa kunci keberhasilan pendidikan agama di sekolah bukan terutama terletak pada metode pendidikan agama yang digunakan dan penguasaan bahan; kunci pendidikan agama di sekolah sebenarnya terletak pada pendidikan agama di dalam rumah tangga.Inti pendidikan agama dalam rumah tangga itu ialah taat kepada Tuhan, hormat kepada orang tua, dan hormat kepada guru. Di sekolah hormat kepada guru inilah kuncinya. Bila anak didik tidak hormat kepada guru, berarti ia juga tidak akan menghormati agama. Bila agama Islam dan guru agama tidak dihormati, maka metode pendidikan agama yang baik pun tidak akan ada artinya. Itulah yang umumnya terlihat sekarang, terutama disekolah umum. Oleh karena itu, pendidikan agama dalam rumah tangga tidak boleh terpisah dari 
pendidikan agama di sekolah; mula-mula adalah pendidikan agama dalam rumah tangga sebagai fondasi, kemudian dilanjutkan di sekolah sebagai pengembangan rinciannya (Tafsir, 2008: 158-159). Dalam kondisi seperti ini, tugas mendidik dalam keluarga menjadi terbantu oleh adanya sekolah, karena saling terkait satu-sama lain.

Setiap orang tua tentu menginginkan anaknya menjadi orang yang berkembang secara sempurna. Mereka menginginkan anak yang dilahirkan itu kelak menjadi orang yang sehat, kuat, berketrampilan, cerdas, pandai dan beriman. Bagi orang Islam, beriman itu adalah beriman secara Islam. Dalam taraf yang sederhana, orang tua tidak ingin anaknya lemah, sakit-sakitan, penganggur, bodoh, dan nakal.Dan terakhir, pada taraf paling minimal ialah jangan nakal. Kenakalan akan menyebabkan orang tua mendapat malu dan kesulitan (Tafsir, 2008: 155). Bahkan, sebagian dari istri dan anak-anak ada yang menjadi musuh, dalam arti bahwa dengan ulahnya, mereka dapat menjerumuskan suami atau ayahnya melakukan perbuatan yang melanggar agama. Namun munculnya tingkah laku itu juga bisa disebabkan ketidak pedulian seorang ayah terhadap anak. Dengan alasan kesibukan menekuni karier atau mengurus bisnis, tak tersisa lagi waktunya untuk ikut serta mendidik anak, padahal peranan orang tua jauh lebih vital dan menentukan dibandingkan dengan dua faktor lainnya: lingkungan dan guru (Asghary, 1994: 215). Mekipun tidak dapat dipungkiri, bahwa manusia hidup di dunia itu memerlukan bekal. Namun hal tersebut semestinya merupakan sarana yang digunakan untuk mencapai ridho-Nya dan bekal untuk di akhirat kelak. 
Banyak orang tua yang berpikir bahwa dengan droping segala keperluan pendidikan dan uang jajan yang besar, semua masalah telah selesai.Tidak sedikit orang tua yang waktunya terhisap oleh kesibukan luar rumah. Tak sempat lagi ia berkumpul secara lengkap dengan keluarga, apalagi berdialog dan membina komunikasi dengan anak. Akibatnya mereka menyerap kebudayaan apa saja dan kemudian cendrung mencintai hura-hura yang dengan sengaja memang disodorkan oleh musuh Islam untuk menghancurkan generasi mudanya (Asghary, $1994: 215)$.

Sekarang ini laju globalisasi banyak mempengaruhi anak-anak dan mengakibatkan lemahnya generasi bangsa. Generasi yang lemah, bukan hanya lemah dalam aspek sosial ekonomi, melainkan juga lemah dalam akidah dan erosi dalam akhlak. Kesenjangan bimbingan orang tua dan miskinnya komunikasi (muwajah, face to face) antara orang tua dan anak, dapat dipergunakan oleh kaum yang dengki kepada Islam untuk meracuni generasi muda itu (Asghary, 1994 : 216). Misalnya, mengajarkan bagaimana cara berpakaian, berkomunikasi, dan bersikap di masa sekarang berbeda dengan apa yang di syari'atkan oleh agama melalui berbagai media.

Anak sering pula menyebabkan orang tua lupa kepada Allah dan rasul-Nya. Mereka sibuk mengurus anak-anaknya. Mereka bekerja matimatian untuk mencari uang agar semua permintaan anaknya dapat dipenuhi, karena cinta kepada anak. Kadang-kadang permintaan yang tidak masuk akal pun dipenuhi, demi cinta kepada anak. Sayang anak menyebabkan orang tua korupsi atau mencuri. Semuanya itu 
menyebabkan orang lupa kepada Allah dan Rasul-Nya (Tafsir, 2008 : $162)$.

Orang tua mendidik anaknya karena kewajaran, karena kodratnya; selain itu karena cinta.Tujuan pendidikan tauhid dalam keluarga ialah agar menjadi anak yang saleh. Tujuan lain adalah kelak anak itu agar tidak menjadi musuh orang tuanya, yang mencelakakan orang tuanya (Tafsir, 2008 : 163). Untuk itu, orang tuabersamaan dengan mencurahkan cinta kasihnya harus pandai-pandai dalam mendidik anak.

Musuh-musuh Islam, baik Yahudi dan Nasrani yang kapitalis (sistem ekonomi dimana perdagangan, industri dan alat-alat dikendalikan oleh pemilik swasta dengan tujuan untuk menguasai ekonomi dunia) maupun yang komunis (mementingkan kepentingan individu dan mengesampingkan kepentingan buruh), pada dasarnya mempunyai sikap yang sama dalam melemahkan Islam melalui pengembangan pemahaman agama kepada pemeluknya. Mereka tidak lagi melihat aktivitas pemurtadan sebagai cara terbaik. Telah lama mereka memiliki cara lain yang lebih efektif, yakni metode menanamkan kesan mencintai kemewahan dan demokrasi pada generasi muda Islam. Demokrasi di sini adalah dalam makna kebebasan untuk tidak patuh kepada orang tua, harus berani menghujatnya dan protes kepada kemutlakan peranan pihak orang tua (Asghary, 1994: 216). Tidak ada lagi yang namanya sikap takzim antara anak dengan orang tua, murid dengan guru, yang lebih muda kepada yang lebih tua umurnya, rasa menghargai serta menyayangi kepada yang lebih muda berubah dengan cara bersikap seolah seperti dengan teman sebayanya dengan kebebasan yang ia miliki. 
Jadi, tujuan mereka kini bukanlah mengumpulkan angka secara kuantitas tentang muslim yang murtad dari agamanya. Generasi muda tetap Islam, tetapi perilaku mereka digiring dan diarahkan kepada perilaku yang bebas tanpa kendali seperti gaya kehidupan remaja di Barat, dimana sang remaja itu diantisipasi untuk bersikap bebas dalam protes kepada orang tua (plus guru), walau cara itutidak sejalan dengan etika dunia beradab. Meracuni cara berpikir mereka untuk memutlakkan kedudukan rasio. Padahal dalam Islam, akal itu bukan segalanya. Akal hanya sebagai alat belaka, bukan akal yang dijadikan agama. Menanamkan sikap kritis yang tidak proposional kepada generasi muda Islam, agar generasi muda itu membuang rasa kepedulian mereka kepada agama. Merangsang generasi muda untuk mencintai hidup santai, hurahura, penuh glamour, serta pergaulan bebas, dan meracuni mereka dengan impian dan khayalan melalui minuman keras, ganja, heroin, narkotik, serta perjudian. Iming-iming hadiah hampir dalam segala bentuk produksi dan jasa telah menimbulkan akibat sampingan yang begitu memprihatinkan dalam masyarakat (Asghary, 1994 : 216-217).

Pendidikan keluarga sangat penting mengingat keluarga menerima anak dalam keadaan belum bisa bicara, belum memiliki pengalaman, dan belum dapat menggunakan sarana komunikasi. Kemudian keluarga memulai proses sosial anak dari kondisi "belum berupa apa-apa", membantunya secara bertahap untuk berinteraksi dengan segala sesuatu yang ada di dalam lingkungan fisik dan sosial, serta mempersiapkannya untuk memasuki lembaga-lembaga masyarakat dan berbagai aktivitas kehidupan pada umumnya. Sebagai pusat 
pendidikan sosial, keluarga tidak menanamkan tujuan dan pikirannya secara langsung kepada anak, bahkan tidak pula kebiasaan-kebiasaan motorik seperti memejamkan mata dan menghindarkan rasa sakit secara refleks. Langkah pertama yang dilakukan keluarga hanyalah mempersiapkan kondisi mendorong individu untuk menguasai sebagian cara kerja nyata. Langkah lain yang bersifat komplementer ialah mengikutsertakan individu di dalam kerja komunitas agar mampu melihat dalam keberhasilan atau kegagalan mereka (Aly dan Munzier, 2003 : 204). Hal ini juga agar dapat menghindarkan anak dari panjang angan-angan serta menumbuhkan rasa menghargai proses dari pada akan suatu hasil.

Secara operasional hal-hal yang dapat dilakukan untuk pendidikan tauhid dalam keluarga bila diterapkan dalam kehidupan sehari-hari di antaranya kondisi kehidupan di rumah tangga menjadi kehidupan Muslim. Misalnya, tidak iri kepada orang lain, dan jujur. Lakukan semua perintah Allah yang wajib dan sunah seperti salat, puasa, zikir, serta berdoa saat akan beraktifitas dan sesudah beraktifitas. .

Maka diperlukan melakukan pembiasaan kepada anak-anak dalam kehidupan sehari-hari. Sejak kecil anak sering dibawa ke masjid, salat, mengaji. Suasana itu akan mempengaruhi jiwanya, masuk kedalam jiwa tanpa melalui proses berpikir. Kenalkan mereka dengan mengucapkan kalimat-kalimat thoyyibah (baik) diantaranya shalawat dan do'a. Pada saat libur sekolah, sebaiknya anak dimasukkan ke pesantren kilat. Pesantren kilat yang terbaik adalah pesantren kilat yang diselenggarakan di pesatren dengan model pendidikan pesantren murni. Libatkan anak ke 
dalam setiap kegiatan keagamaan di kampung, seperti panitia Ramadhan, panitia zakat fitrah, panitia idul fitri dan idul qurban, panitia pengajian anak-anak.

Keterlibatan ini bermakna sangat penting bagi pendidikan agama anak. Ia mulai mengetahui dan mengalami tanggung jawabnya sebagai petugas Allah, mulai memperhatikan pembinaan agama Allah. Ia akan menyadari sedikit demi sedikit bahwa dirinya harus beragama dengan baik. Ganjil jika anak mengurus kegiatan agama, sedangkan dirinya sendiri tidak beragama dengan benar.Semua ini memerlukan dukungan dari kedua orang tua, juga dari anggota masyarakatnya.

Pendidikan agama di sekolah hanya bersifat membantu, terutama membantu dalam menambah pengetahuan anak.Memang, sekolah juga diharapkan dapat menanamkan iman dalam hati anak didiknya, tetapi kemungkinan berhasilnya amat kecil. Oleh karena itu, sekali lagi kerja sama sekolah dengan rumah tangga amat perlu, terutama dalam pendidikan agama anak (Tafsir, 2008: 188-189). Dengan maksud agar anak merasa nyaman dan merasa tidak terbebani dalam menjalani berbagai aturan hidup yang berlaku, dan dapat menjadi bekal untuk diwariskan kepada anak cucunya kelak.

\section{Kesimpulan}

Ibnu Katsir adalah seorang ahli tafsir dan sejarah ternama. Ia juga seorang ahli fiqih dan ahli hadis. Nama lengkapnya adalah Abu al-Fida, Imaduddin Ismail Ibnu Umar Ibnu Katsir al-Quraisyi al-Basrawi adDimasyqi, yang terkenal dengan IbnuKatsir. Banyak karya-karya Ibnu 
Katsir, salah satunya yaitu Tafsir Al Qur'an Al 'adzim yang termasyhur dengan Tafsir IbnuKatsir. Ibnu Katsir lahir pada tahun 700 H/1300 M di timur Bashri yang masuk wilayah Damaskus dan wafat pada tahun $774 \mathrm{H}$ di Damaskus.

Guru pertama yang membimbing Ibnu Katsir ialah Burhanuddin al-Fazari, seorang ulama penganut mazhab Syafi'i. Banyak karya-karya ilmiah yang diwariskan oleh Ibnu Katsir di antaranya ialah Tafsîr al Qurân al 'Azîmkitab ini termasyhur dengan sebutan Tafsir Ibnu Katsiryang berjumlah sepuluh juz.

Kitab Tafsir ini penulisannya dimulai setelah Ibnu Katsir diangkat menjadi guru besar oleh Gubernur Mankali Bugha di Masjid Umayyah, Damaskus, pada tahun 1366 M. Tafsir Ibnu Katsir yaitu tafsir yang terkenal dengan tulisan ma'tsur/tafsir bi al-riwayah. Cara Ibnu Katsir dalam menafsirkan al-Qur'an pertama-tama dengan menyebutkan satu ayat kemudian menafsirkannya dengan redaksi yang mudah serta ringan dan menyertainya dengan dalil-dalil dari ayat yang lain, lalu membandingkan ayat-ayat tersebut sehingga arti dan maksudnya menjadi jelas.

Konsep pendidikan tauhid dalam keluarga menurut Ibnu Katsir yang terkandung dalam Qur'an Surat al Baqarah ayat 132-133 adalah, upaya membina manusia dalam menyerahkan diri secara mutlak kepada Allah SWT dan tidak menyekutukan-Nya dengan sesuatu apapun sepanjang hayatnya pada suatu kelompok di mana manusia hidup dan menetap secara berkesinambungan sampai keturunannya di masa depan kelak meskipun berbeda cara atau metode dalam pelaksanaannya. 
Ada Relevansi atau hubunga nsaling keterkaitan antara pendidikan tauhid dalam keluarga yang terkandung dalam Qur'an Surat al Baqarah ayat 132-133 dalam Tafsir Ibnu Katsir dengan kehidupan sehari-hari tentang pentingnya penanaman pendidikan tauhid yang harus dilakukan sejak dini untuk membentuk karakter kepribadian yang kuat yaitu supaya terus berpegang teguh pada agama Islam sampai akhir hayat. Terlebih di era globalisasi yang memberikan banyak kemudahan namun tidak jarang juga memberikan dampak negatif kepada manusia. Sehingga pendidikan tauhid adalah sebagai pondasi paling penting untuk membentengi manusia agar dapat memilih yang positif dan membuang yang negatif. Karena tauhid adalah tujuan dari semua segi kehidupan manusia.

Melalui pendidikan tauhid dalam keluarga pada Qur'an Surat al Baqarah ayat 132-133 dalam Tafsir Ibnu Katsir ini adalah salah satu cara penyampaian penanamam nilai-nilai pendidikan tauhid yang tidak akan terlupakan oleh anak-anak dikarenakan penyampaian pesan tersebut dilakukan oleh seorang bapak kepada anak-anaknya menjelang akhir hidupnya (sakaratul maut). Tidak hanya menyampaikan bagaimana cara mendidik anak dan menanamkan tauhid kepada anak namun juga menghadirkan karakter kepribadian seorang ayah yang patut diteladani. Karena seorang anak adalah generasi penerus bangsa selanjutnya. Dan bangsa yang kuat adalah ketika memiliki generasi penerus yang kuat, yang tidak hanya berpengetahuan dan pandai namun juga memiliki karakter kepribadian yang kuat melalui pendidikan tauhid dalam keluarga. 
Mudarrisa, Jurnal Kajian Pendidikan Islam, Vol. 6, No.2, Desember 2014: 277-300

\section{Daftar Pustaka}

Dahlan, Abd. Rahman. 1997. Kaidah-kaidah Penafsiran Al Qur'an. Bandung: Mizan.

Daradjat, Zakiah. 1970. Ilmu Jiwa Agama. Jakarta: Bulan Bintang. . 2011. Ilmu pendidikan Islam. Jakarta: Bumi Aksara.

Departemen Agama Republik Indonesia. 1993. Al Qur'an dan Terjemahannya. Semarang: CV. Al Waah.

Hasbullah. 2009. Dasar-dasar Ilmu Pendidikan. Jakarta: Rajawali Pers.

IAIN Syarif Hidayatullah. 1992. Ensiklopedi Islam Indonesia. Jakarta: Djambatan.

Islamuddin, haryu. 2012. Psikologi Pendidikan. Jember: STAIN Jember Press.

Kurniasih, Imas. 2010. Mendidik SQ Anak Menurut Nabi Muhammad $S A W$. Yogyakarta: Pustaka Marwa

Marijan. 2012. Metode Pendidikan Anak: Membangun Karakter Anak yang Berbudi Mulia, Cerdas dan Berprestasi. Yogyakarta: Sabda Mulia.

Pusat Bahasa Departemen Pendidikan Nasional. 2007. Kamus besar Bahasa Indonesia. Jakarta: Balai Pustaka.

Quraish Shihab, M. 2012. Al Lubab: Makna, Tujuan dan Pelajaran Dari Surah-surah al Qur'an. Tangerang: Lentera Hati.

Zuhaili, Wahbah.1995. Al Qur'an Paradigma Hukum dan Peradaban. Surabaya: Risalah Gusti.

Zurayk, Ma'ruf. 1994. Aku dan Anakku: Bimbingan Praktis Mendidik Anak Menuju Remaja. Bandung: Al Bayan. 